\title{
МОРСКИЕ МИКРОСКОПИЧЕСКИЕ ГРИБЫ - ПОТЕНЦИАЛЬНЫЕ ИСТОЧНИКИ НОВЫХ ФАРМАЦЕВТИЧЕСКИ ЗНАЧИМЫХ СОЕДИНЕНИЙ
}

\author{
А.Н.Юрченко \\ Лаборатория химии микробных метаболитов, \\ Тихоокеанский институт биоорганической химии им. Г.Б. Елякова ДВО РАН, \\ 690022, Россия, г. Владивосток, пр. 100-летия Владивостока, 159.
}

DOI: 10.19163/MedChemRussia2021-2021-295

E-mail:yurchant@ya.ru

Микроскопические грибы являются известными продуцентами биологически активных соединений. Наземные экоформы таких грибов стали первоисточниками таких лекарственных соединений [1], таких как антибиотик пенициллин, гипохолистеринемический препарат ловастатин [2] и финголимод (1) для лечения рассеянного склероза [3].

Морские грибы все еще мало изучены, но имеют не меньший потенциал: в морском грибе рода Cephalosporium был впервые обнаружен цефалоспорин C [4].<smiles>C=C(C)[C@H]1COc2c(C)cc3oc4c([C@H](O)C(C)(C)O)ccc(O)c4c(=O)c3c2[C@@H]1OC(C)=O</smiles><smiles>COc1c(C)c2c(c3c1CC(C(C)C(=O)O)O3)C(=O)OC2O</smiles>

За последние пять лет из морских грибов было выделено 246 новых биоактивных соединений. Противовирусная активность была показана для 12 из них, антибактериальная - для 57, противоопухолевая - 62, цитопротекторная - 70. Такие антибактериальные вещества как эмериксантон E (2) и пеникацид D (3) представляют особый интерес, поскольку действуют на патогены, рекомендованные ВОЗ как приоритетные мишени для новых антибиотиков.

Современные вызовы приводят к интенсификации изучения биологически активных вторичных метаболитов морских грибов, причем кроме традиционных направлений исследования антибактериальной и цитотоксической активностей значительно увеличивается интерес к цитопротекторным соединениям.

Работа частично поддержана за счет средств РФФИ (грант № 21-53-54005).

\section{Литература}

[1] J.H. Powers, Clin. Microbiol. Infect. 2004, 10, 23-31.

[2] A.W. Alberts, J. Chen, G. Kuron et al, Proc. Natl. Acad. Sci. U.S.A. 1980, 77, 3957-3961.

[3] C.R. Strader, C.J. Pearce, N.H. Oberlies, J. Nat. Prod. 2011, 74, 900-907.

[4] G.G.F. Newton, and E.P. Abraham, Nature 1955, 175, 548. 